\title{
Maatalouspolitiikan vaikutus pellon käyttöön
}

\author{
Jarkko Niemi $^{1)}$ \\ 1) Maa- ja elintarviketalouden tutkimuskeskus, taloustutkimus, PL 3, 00411 Helsinki, jark- \\ ko.niemi@mtt.fi
}

\section{Johdanto}

Suomessa aloitettiin viljan tuotantoon kohdistuvan maatalouspolitiikan uudistukset 1980-luvun lopussa. Myöhemmin uudistukset ovat jatkuneet EU:n yhteisen maatalouspolitiikan mukana. Uudistusten myötä tuotantoyksikköihin perustuvan suoran tuen käyttö on lisääntynyt ja viljojen tuottajahintoja on alennettu. Samalla kun maatalouspolitiikkaa on uudistettu, rukiin ja vehnien kokonaisviljelyalat Suomessa ovat vaihdelleet runsaasti. Vähäisen viljelyn ja heikkojen satovuosien vuoksi kotimaisen leipäviljan tuotanto ei pääsääntöisesti riittänyt kattamaan kotimarkkinoiden kulutusta 1990-luvulla (MMM 1999, s. 187).

Peltokasvien viljelyaloihin vaikuttavat hintasuhteet ja maan ominaisuudet, kuten lohkon sijainti ja satoisuus (mm. Lichtenberg 1989, Wu ja Brorsen 1995, Hardie ja Parks 1997). Lisäksi pintaalaperusteiset tuet voivat vaikuttaa viljelyaloihin. Jos tukipolitiikka suosii jonkin kasvin viljelyä muiden kasvien kustannuksella, voidaan peltoa ja muita resursseja allokoida markkinoilla vallitsevista hintasuhteista ja muista olosuhteista riippumatta (von Massow ja Weersink 1993). Vilja-alojen suuren vaihtelun Suomessa on arveltu johtuvan leipäviljoille epäedullisista sääolosuhteista ja tukiratkaisuista sekä alhaisista tuottajahinnoista suhteessa rehuviljaan. Esimerkiksi leipä- ja rehuviljojen tuottajahintaero kaventui EU-jäsenyyden myötä (MMM 1999, s. 176) ja vehnälle ei maksettu ensimmäisinä EUjäsenyysvuosina epäsuotuisten alueiden LFA-tukea. Siirtymäkaudella alhaisten tukien onkin arveltu vähentäneen vehnän viljelyä etenkin A-tukialueen ulkopuolella (mm. MMM 2000, Salo 2000).

Sääriskiin ei voida juurikaan vaikuttaa, mutta suorat tulotuet ovat yhteiskunnan päätettävissä. Aivan viime vuosina leipäviljojen viljelyä onkin pyritty edistämään kohottamalla pinta-alatukia ja kehottamalla sopimustuotantoon. Hinta- ja tukipolitiikan ongelmista huolimatta maatalouspolitiikan vaikutuksia pellon allokointiin leipä- ja rehuviljojen kesken ei kuitenkaan ole tutkittu Suomessa tilastollisin menetelmin. Tämän tutkimuksen tavoitteena on selvittää, miten maatalouspolitiikalla voidaan vaikuttaa leipä- ja rehuviljojen viljelyn laajuuteen. Tutkimuksen päätavoitteena on selvittää, onko harjoitettu maatalouspolitiikka ohjannut viljatilojen pellon käyttöä jonkin kasvin suuntaan ja kuinka suuri mahdollinen ohjaava vaikutus on ollut.

\section{Aineisto ja menetelmät}

Tutkimusaineisto koostuu MTT taloustutkimuksen kannattavuuskirjanpitoon vuosina 1989-1998 osallistuneista kasvintuotantoon erikoistuneista tiloista. Aineistossa on yhteensä 2510 havaintoa (240 260 havaintoa/vuosi). Osa tiloista on erikoistunut pelkkään viljanviljelyyn, mutta osalla tiloista viljellään runsaasti myös erikoiskasveja, kuten sokerijuurikasta. Tutkimuksessa estimoidaan pellon allokointiosuuksia kuvaavat yhtälöt kevätvehnälle, syysvehnälle, rukiille, rehuviljalle (ohra ja kaura yhdistettynä) ja vapaaehtoiselle kesannolle. Yhtälöiden perusteella lasketaan pellon allokaatiojoustot, joilla tarkastellaan pellon käyttöä. Yhtälöt estimoidaan samanaikaisesti yhtälöryhmänä, sillä yhtälöiden virhetermit voivat korreloida viljojen tuotantopäätösten kytkeytyessä toisiinsa viljelykierron kautta. Esimerkiksi kasvinvuorottelulla voidaan parantaa maan kasvukykyä monokulttuuriin verrattuna (Talvitie ym. 1988).

SUR-regressiomalli (Seeminly unrelated equations) huomioi virhetermien korrelaation yhtälöiden välillä. SUR:lla saavutettu hyöty onkin sitä suurempi mitä enemmän virhetermit korreloivat keskenään (Intriligator ym. 1996, s.133-136). Tässä estimoitavat syys- ja kevätviljayhtälöt eroavat toisistaan hintamuuttujien suhteen, joita mitataan kylvövuoden hinnoilla. Yhtälöt voidaan esittää seuraavasti:

$$
\begin{gathered}
A_{t}^{i}=A_{i} / A_{j}^{\text {koko }}=P_{t} \beta_{P}+W_{t} \beta_{W}+G_{t} \beta_{G}+A_{j}^{\text {total }} \beta_{A}+S_{j, t} \beta_{S}+u_{t}^{i}, \\
\text { siten että } i=1,2,3,4,5,6 \text { ja } \sum_{i=1}^{6} A_{t}^{i}=1,
\end{gathered}
$$


missä osuusmuuttuja $A_{t}^{i}$ kuvaa kasville $i$ allokoidun pellon osuutta tilan $j$ käytettävissä olleesta kokonaispeltoalasta $A_{j}$, $W_{t}$ tuotantopanosten hinnat, $G_{t}$ pellon allokointiin vaikuttavat pinta-alatuet, $A_{j}^{\text {total }}$ tilan $j$ kokoa (peltoala) kuvaavan muuttujan ja $S_{j, t}$ syysviljojen kylvöolosuhteita sekä tilan sijaintia kuvaavat apumuuttujat. $\beta_{P}, \beta_{W}, \beta_{G}, \beta_{A}$ ja $\beta_{S}$ ovat muuttujia vastaavat parametrit. Kasvien $i$ pinta-alat summautuvat tilan kokonaispinta-alaksi $A_{j}^{\text {koko }}$, joka rajoittaa tuotantoprosessia. Tutkimusajanjaksolla pellon käyttöä on rajoitettu velvoitekesannoinnilla. Tämän vuoksi hallinnollisesti määrätty kesantovelvoite vähennetään viljelyosuutta muodostettaessa tilan kokonaispinta-alasta, koska se on määrätty tilan tuotantoresurssien ulkopuolelle. Sen sijaan velvoitteen ylittävältä osalta viljelijä tekee kesannointipäätöksen vapaaehtoiselle kesannolle maksettavan palkkion perusteella. Viljelyosuuksien summa on yksi $\left(\sum A_{t}^{i}=1\right)$, joten yhtälö "muut kasvit" on pudotettava estimoinnista pois. Näin varmistetaan, että virhetermien varianssimatriisi on yhdestä poikkeava ja että mallin estimointi on mahdollista (Johnston 1972).

Suorat tuet, kesantovelvoitteet ja hinnat huomioidaan tilakohtaisesti, mutta kuitenkin niin, että ne ovat viljelijän näkökulmasta tilan ulkopuolelta annetut eli eksogeeniset. Tuet lasketaan tilakohtaisesti sen mukaan, kuinka suureen hehtaarikohtaiseen tukeen tila on tukiehtojen mukaan oikeutettu. Viljelijän oletetaan olevan hinnanottaja, joka allokoi peltoa vallitsevien olosuhteiden ja hintaodotusten perusteella. Tuotantopäätösten tekohetkellä vallitsevien hintaodotusten oletetaan vastaavan ennustevirheistä huolimatta keskimäärin toteutuneita hintoja. Rehuviljan hintana käytetään aineiston viljelyaloilla painotettua rehuohran ja rehukauran hinnan keskiarvoa. Rukiin ja vehnän hintoina käytetään tuottajille maksettua markkinahintaa, johon on lisätty hintatuki. Lannoitteiden hintaindeksiä käytetään viljelykustannusten indikaattorina, sillä lannoitus vaikuttaa keskeisesti viljojen tuotantokustannuksiin. Hintamuuttujat saadaan MMM:n tietopalvelukeskuksen tilastoista. Kaikki hinnat ja tuet normeerataan jakamalla ne rehuviljan hinnalla.

Koko maan kirjanpitotilat sisältävä tila-aineisto jaetaan alueisiin, jotka muodostuvat viljelyvyöhykkeistä I-V. Viljelyvyöhykkeitä käsitellään apumuuttujina, jotka saavat arvon yksi, kun tila sijaitsee kyseisellä viljelyvyöhykkeellä ja muuten arvon nolla. Lisäksi syyskylvöjen sääoloja vuonna $t$ mitataan apumuuttujalla, sillä kasvukauden alun ja lopun lämpö- ja sadeolot vaikuttavat viljojen tuotantomahdollisuuksiin (Rantanen 1983). Säämuuttuja saa arvon 1, kun kylvöolot ovat poikkeuksellisen huonot ja muulloin arvon 0. Apumuuttuja määräytyy keskimääräisen sään mukaan, sillä tilakohtaisista eroista huolimatta säämuutokset ovat yleensä samansuuntaisia koko maassa (Rantanen 1983).

\section{Tulokset ja tulosten tarkastelu}

Malleissa erottuivat selvimmin tilakoon, vehnän ja lannoitteiden hinnan sekä kasvin oman tuen vaikutukset viljelyaloihin. Lähes kaikki muuttujat vaikuttivat 5 prosentin riskillä tilastollisesti merkitsevästi syys- ja kevätvehnän osuuteen tilan peltoalasta (taulukko 1). Esimerkiksi vehnän tuen noustessa tuhannella markalla kevätvehnän viljelyosuus lisääntyi lähes 15 prosenttiyksikköä. Ruis, rehuvilja ja kesantoyhtälöissä kertoimien keskivirheet olivat suuremmat kuin vehnäyhtälöissä. Rehuviljayhtälössä kertoimet olivat kuitenkin vakaita yhtälön spesifioinnista riippumatta. Hintamuuttujien lisäksi tilan sijainti vaikutti merkittävästi pellon käyttöön. Vaihtoehdot pellon käytölle vähenevät pohjoiseen päin mentäessä, joten on luonnollista, että samalla rehuviljan viljely ja kesannointi lisääntyivät ja leipäviljan viljely väheni siirryttäessä etelästä pohjoiseen.

Tämän tutkimuksen käytettävissä oli aineistoa niin lyhyeltä aikaväliltä, että siitä ei voitu estimoida luotettavasti eri malleja vuosille 1989-1994 ja 1995-1998. Myöskään kertoimien vakauden testaaminen esimerkiksi Chow'n ennen ja jälkeen Suomen liittymisen EU:iin testillä ei ollut mahdollista. Suomen liityttyä EU:iin vilja-aloille maksettavien tukien vaihtelu on kuitenkin lisääntynyt. Erikseen estimoiduissa malleissa kertoimien keskivirheet olivat suuret ja eivätkä useat hinta- ja tukimuuttujien kertoimet olleet merkitseviä. Lisäksi multikollineaarisuus haittasi joidenkin muuttujien estimointia kahdelle eri ajanjaksolle. Tässä esitettyjen tulosten perusteella voitaneen kuitenkin arvioida sitä, miten tukipolitiikka on vaikuttanut kasvintuotantotilojen pellon käyttöön.

Pellon käyttö on varsin herkkä viljojen hintasuhteiden muutoksille. Jo pennin muutos hinnoissa saattaa vaikuttaa useita prosentteja kasvien viljelyosuuksiin. Tämä ilmenee myös taulukon 2 joustoista. Vehnien ja rehuviljan viljelyosuudet olivat erittäin joustavia vehnän hinnan suhteen, eli vehnän hinnan noustessa sen viljelyosuus muuttui suhteellisesti mitaten enemmän kuin vehnän hinta. Esimerkiksi prosentin nousu vehnän hinnassa lisäsi kevätvehnän osuutta tilan pinta-alasta vajaat 6 prosenttia. Kevätvehnäala oli joustava myös rukiin hinnan ja rehuvilja-alalle maksettavan tuen suhteen, joiden noustessa prosentilla kevätvehnäala aleni runsaan prosentin. 
Taulukko 1. Pellon allokointimallien estimointitulokset ja kertoimien keskivirheet (suluissa).

\begin{tabular}{|c|c|c|c|c|c|}
\hline Muuttuja & Syysvehnä & Kevätvehnä & Ruis & Rehuvilja & Kesanto \\
\hline \multirow[t]{2}{*}{$\overline{\text { Vakio }}$} & $-0,149238$ & $-0,246737$ & $-0,046107$ & 1,20186 & $-0,044254$ \\
\hline & $(-0,03932)$ & $(0,09323)$ & $(0,038965)$ & $(0,261406)$ & $(0,114723)$ \\
\hline \multirow[t]{2}{*}{ Tilan pinta-ala (ha) } & 0,000232877 & 0,000049145 & 0,000146776 & 0,000448836 & $-0,000706182$ \\
\hline & $(0,0000357324)$ & $(0,0000965187)$ & $(0,0000469332)$ & $(0,000170165)$ & $(0,0000703878)$ \\
\hline \multirow[t]{2}{*}{ Rukiin hinta (mk/kg) } & $-0,044035$ & $-0,082922$ & 0,074694 & 0,075122 & $-0,024009$ \\
\hline & $(0,017004)$ & $(0,033122)$ & $(0,020336)$ & $(0,057364)$ & $(0,024218)$ \\
\hline \multirow[t]{2}{*}{ Vehnän hinta (mk/kg) } & 0,19862 & 0,457765 & a) & $-0,613919$ & $-0,054631$ \\
\hline & $(0,029501)$ & $(0,066944)$ & a) & $(0,17479)$ & $(0,076513)$ \\
\hline \multirow[t]{2}{*}{ Lannoitteen hinta } & $-0,027015$ & $-0,113367$ & $-0,09868$ & $-0,083693$ & 0,196517 \\
\hline & $(0,010734)$ & $0,034(888)$ & $(0,014267)$ & $(0,071823)$ & $(0,030781)$ \\
\hline \multirow[t]{2}{*}{ Vehnän tuki (1 000 mk/ha) } & 0,02113 & 0,146081 & $-0,00170316$ & $-0,113882$ & 0,010548 \\
\hline & $(0,00356289)$ & $(0,00900343)$ & $(0,0048452)$ & $(0,015937)$ & $(0,00661431)$ \\
\hline \multirow[t]{2}{*}{ Rukiin tuki (1 000 mk/ha) } & a) & a) & 0,00823427 & $-0,041333$ & $-0,00326251$ \\
\hline & a) & a) & $(0,00686387)$ & $(0,035595)$ & $(0,015916)$ \\
\hline \multirow[t]{2}{*}{ Rehuviljan tuki (1 000 mk/ha) } & $-0,018242$ & $-0,107879$ & 0,012047 & 0,177412 & $-0,081727$ \\
\hline & $(0,00350678)$ & $(0,011354)$ & $(0,00781322)$ & $(0,052846)$ & $(0,02348)$ \\
\hline \multirow{2}{*}{ Kesantopalkkio (1 000 mk/ha) } & $-0,00559795$ & 0,00490089 & 0,00493128 & $-0,02686$ & 0,088257 \\
\hline & $(0,00286153)$ & $(0,00819702)$ & $(0,00378034)$ & $(0,014685)$ & $(0,00612621)$ \\
\hline \multirow[t]{2}{*}{ Viljelyvyöhyke 2} & $-0,020329$ & $-0,104435$ & $-0,00691262$ & 0,129281 & 0,00382989 \\
\hline & $(0,00264935)$ & $(0,00729616)$ & $(0,00349276)$ & $(0,01286)$ & $(0,00532304)$ \\
\hline \multirow{2}{*}{ Viljelyvyöhyke 3} & $-0,026188$ & $-0,145583$ & $-0,013439$ & 0,158824 & 0,061675 \\
\hline & $(0,00305522)$ & $(0,00849035)$ & $(0,00403775)$ & $(0,014952)$ & $(0,00619019)$ \\
\hline \multirow[t]{2}{*}{ Viljelyvyöhyke 4-5 } & $-0,029364$ & $-0,151456$ & $-0,00496305$ & 0,120813 & 0,112241 \\
\hline & $(0,00486539)$ & $(0,013304)$ & $(0,00640247)$ & $(0,023432)$ & $(0,00969519)$ \\
\hline \multirow[t]{2}{*}{ Syyskylvöjen sää } & $-0,011183$ & $-0,013541$ & 0,029353 & $-0,010081$ & $-0,00352738$ \\
\hline & $(0,0042526)$ & $(0,00903807)$ & $(0,00552799)$ & $(0,016113)$ & $(0,00670213)$ \\
\hline Mallin selitysaste & $13,4 \%$ & $32,7 \%$ & $5,5 \%$ & $12,9 \%$ & $21,4 \%$ \\
\hline
\end{tabular}

a) Parametria ei voitu estimoida.

Syysvehnän osuus tilan peltoalasta oli erittäin joustavaa leipäviljojen hintamuutosten suhteen. Vehnäalalle maksettavan tuen muutoksen suhteen syysvehnäala oli lähes yksikköjoustavaa. Lisäksi prosentin nousu lannoitteiden hinnassa tai rehuvilja-alalle maksettavassa tuessa vähensi syysvehnän viljelyosuutta noin prosentin. Kesantopalkkion ja tilan koon joustot saivat arvon 0,5. Tilan pinta-alan kasvaessa syysvehnän viljelyosuus kuitenkin nousi enemmän kuin muiden kasvien viljelyosuus, joten tilakoon kasvu näytti vaikuttavan eniten syysvehnän viljelyyn.

Rukiin osuus tilan peltoalasta lisääntyi runsaat 3 prosenttia rukiin hinnan noustessa prosentin. Myös lannoitteiden hinnan noustessa tuottajat vähensivät rukiin viljelyä erittäin joustavasti. Sen sijaan viljelyaloille maksettavilla tuilla ei näyttänyt olevan merkitsevää vaikutusta rukiin viljelyyn, sillä pellon allokointi rukiille oli joustamatonta tukimuutosten suhteen ja t-testiarvot olivat alhaisia.

Rehuviljan viljely reagoi joustavimmin rehuviljan ja vehnän hintasuhteen muutoksiin. Vehnän hinnan noustessa prosentin rehuviljan viljely väheni 2 prosenttia. Myös vehnäaloille maksettavat tuet vaikuttivat tilastollisesti merkitsevästi mutta joustamattomasti rehuviljan viljelyalaan. Sen sijaan rehuvilja-alalle maksettavan tuen noustessa prosentilla rehuviljan viljely lisääntyi runsaat puoli prosenttia.

Vapaaehtoisen kesannon osuus tilan peltoalasta nousi 2 prosenttia, kun kesantopalkkiota koro-

Taulukko 2. Pellon allokaation joustot ja niiden tilastollinen merkitsevyys.

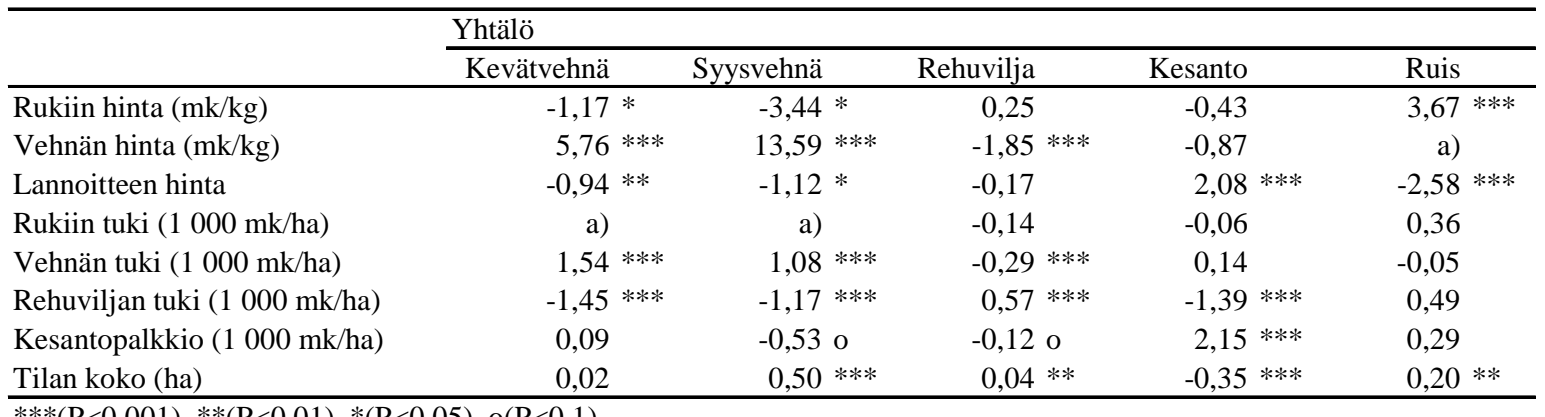

$* * *(\mathrm{P}<0.001), * *(\mathrm{P}<0.01), *(\mathrm{P}<0.05), \mathrm{o}(\mathrm{P}<0.1)$

a) Joustoa ei voitu estimoida.

tettiin prosentilla. Myös lannoitteiden hinnan noustessa viljelijät lisäsivät kesannointia joustavasti. Leipävilja-aloille maksettavat tuet eivät vaikuttaneet merkitsevästi kesantoaloihin. Sen sijaan rehuvilja-aloille maksettavan tuen noustessa kesannon osuus tilan peltoalasta väheni joustavasti. 


\section{Johtopäätökset}

Tukipolitiikalla ja viljojen hintasuhteilla näyttää olevan erittäin suuri vaikutus siihen, kuinka paljon leipä- ja rehuviljoja Suomessa viljellään. Etenkin vehnien viljelyalat reagoivat erittäin joustavasti viljojen hinnoissa tapahtuneisiin muutoksiin. Tehokas keino lisätä vehnän viljelyä lieneekin maksaa sille nykyistä korkeampaa tuottajahintaa. Tässä tutkimuksessa estimoidut joustot, siirtymäkaudella vehnäaloille maksetut alhaiset pinta-alatuet sekä rehu- ja leipäviljojen hintaeron kaventuminen Suomen EUjäsenyyden myötä viittaavat siihen, että pinta-alatukiin perustuva maatalouspolitiikka vähentää vehnän viljelyä ja lisää rehuviljan viljelyä. Näkemystä tukee myös se, että viljojen tuottajahintojen laskun ja pinta-alaperusteisten tukien käytön lisääntyessä mm. vehnän viljelyn kannattavuus on saattanut alentua, jolloin viljelyn säilyminen kannattavana voi riippua aikaisempaa useammin hinta- ja satoriskien toteutumisesta (vrt. Isosaari 1995).

Myös lannoitepanoksen hinnalla näyttää olevan suuri vaikutus leipäviljojen viljelyyn ja kesannointiin. Lannoitteiden hinnan noustessa viljelijät lisäsivät kesannointia joustavasti ja vähensivät runsaasti lannoitepanosta vaativien leipäviljojen viljelyä. Lisäksi kesantopalkkion ja vilja-aloille maksettavan tuen eron kaventuminen lienee osaltaan kannustanut vapaaehtoisen kesannoinnin vähentämiseen.

Tilakoon kasvaessa syysviljojen viljely lisääntyy ja kesannointi vähenee. Tulos liittynee siihen, että syysviljojen tuotantoa lisäämällä viljelijä voi pidentää sadonkorjuuseen käytettävissä olevaa aikaa ja pienentää kevätkylvöjen työhuippua saavuttaen näin mittakaavaetuja. Lisäksi kasvivalikoiman laajentaminen tilakoon kasvaessa voi hajauttaa hinta- ja satoriskiä. Pinta-alaltaan suurten tilojen kasvivalikoima saattaakin olla monipuolisempi kuin pinta-alaltaan pienten tilojen. Myös viljan yksikkötuotantokustannus alenee tilakoon kasvaessa, mikä korottaa vaihtoehtoiskustannusta.

Hintasuhteiden muutos saattaa vaikuttaa teknologiseen kehitykseen ja siten viljelyalojen hintaresponssiin. Tässä tutkimuksessa käytetty aineisto ei kuitenkaan riittänyt erillisten mallien estimointiin ja kertoimien testaamiseen ennen ja jälkeen Suomen liittymisen EU:iin. Tästä huolimatta esitettyjen tulosten voidaan katsoa antavan viitteitä siitä, miten viljelijät ovat huomioineet tuki- ja hintamuutoksen pellon käytössä. Mallinnettaessa pellonkäyttöä jatkossa olisi myös hyödyllistä kiinnittää enemmän huomiota siihen, miten riskitekijät vaikuttavat pellon käyttöön ja etenkin syysviljojen viljelyyn. Tässä tutkimuksessa käytettiin syyskylvöjen sääoloja kuvaamaan apumuuttujaa. Näyttää kuitenkin siltä, että apumuuttuja ei kuvannut tarkasti syyskylvöjen sääoloja muun muassa alueellisen säävaihtelun vuoksi.

\section{Kirjallisuus}

Hardie, I.W. \& Parks, J.P. 1997. Land Use wiht Heterogenous Land Quality: An Application on an Area Base Model. American Journal of Agricultural Economics 79: 299 - 310.

Isosaari, H. 1995. EU-jäsenyyden vaikutus kasvinviljelyä harjoittavan tilan tuotantoon. Pellervon taloudellisen tutkimuslaitoksen raportteja ja artikkeleita 136. Espoo. $47 \mathrm{~s}$.

Intriligator, M.D., Bodkin, R.G. \& Hsiao, C. 1996. Econometric Models, Techiques, and Applications. Prentice Hall, New Jersey. 653 p.

Johnston, J. 1972. Econometric Methods. McGraw-Hill Kogakusha, Tokio.437 p.

Lichtenberg, E. 1989. Land Quality, Irrigation Development and Cropping Patterns on the Northern High Plains. American Journal of Agricultural Economics 71: 187 - 194.

von Massow, M. \& Weersink, A. 1993. Acreage Response to Government Stabilization Programs in Ontario. Canadian Journal of Agricultural Economics 41: 13 - 26.

MMM 1999. Maatilatilastollinen vuosikirja 1998. SVT. Maa-, metsä- ja kalatalous, 1999:12. Maa- ja metsätalousministeriö, Helsinki. $262 \mathrm{~s}$.

MMM 2000. Vehnä 2005. Kansallisen vehnäohjelman loppuraportti. Viitattu 20.11.2000. Saatavilla: http://www.mmm.fi/mao/vilja/default.htm

Rantanen, O. 1983. Sääolot ja kevätviljanviljely. Leipä leveämmäksi 2: 5-6.

Salo, Y. 2000. Syysvehnä. Julkaisussa: MKL 2000. Peltokasvilajikkeet 2000. Tieto tuottamaan 87. MKL:n julkaisuja no 951. p. 32 - 34.

Talvitie, H., Ruippo, J. \& Hannukkala, A. 1988. Esikasvin valinta - tärkeä osa rukiin viljelytekniikkaa. Koetoiminta ja käytäntö 26.1.1988. p. 6.

Wu, J. \& Brorsen, W.B. 1999. The Impact of Government Programs and Land Charasteristics on Cropping Patterns. Canadian Journal of Agricultural Economics 43: 87 - 104. 